\title{
Historia ciała, tom 2 (Od Rewolucji do I wojny światowej), red. A. Corbin, przeł. K. Belaid i T. Stróżyński, słowo/obraz terytoria, Gdańsk 2013
}

\section{(c) $(1)$}

http://dx.doi.org/10.12775/KLIO.2014.066

\begin{abstract}
WU chwili, gdy piszę te słowa, zdążył się już w Polsce ukazać trzeci i ostatni tom Historii ciała pod redakcją francuskich historyków: Alaina Corbina, Jean-Jacques'a Courtine’a i Georges’a Vigarello. Aktualnie zatem dysponujemy całością tego historiograficznego przedsięwzięcia, co pozwala podjąć próbę ogólnego namysłu nad jego spójnością, wewnętrzną logiką, relacjami między poszczególnymi tomami; możemy też już zapytać, czy z analiz obecnych we wszystkich tomach wyłania się jakaś zasadnicza linia ewolucyjna, ukazująca historyczność ciała w kulturze europejskiej od wczesnej nowożytności do czasów współczesnych? Ponieważ jednak chodzi o przedsięwzięcie zakrojone na bardzo szeroką skalę (łącznie ponad 1000 stron, kilkudziesięciu autorów poruszających różnorodne aspekty związane
\end{abstract}


z ciałem), a jego główny temat - „ciało” - jest przedmiotem badawczym, który ma w naukach humanistycznych złożony i niejednoznaczny status, satysfakcjonujące rozstrzygnięcia owych ogólnych problemów i pytań wymagają z pewnością głębokiej analizy ujętej co najmniej w formie osobnego artykułu. Tutaj natomiast, w ramach krótkiej recenzji, chciałbym się jedynie pokusić o sformułowanie kilku wstępnych uwag w odniesieniu do drugiego tomu, które jednak będą też, w mniejszym lub większym stopniu, dotyczyć całej Historii ciata.

Ciało nie jest dopiero co „odkrytym” przedmiotem badań historycznych. Przeświadczenie, że nie sprowadza się ono wyłącznie do porządku natury, lecz że kształtują je również mechanizmy kulturowe lub cywilizacyjne, a więc czynniki zmienne, tymczasowe, decydujące o historyczności ciała - przeświadczenie to nie wzbudza obecnie większych kontrowersji, a jego początki sięgają przynajmniej pierwszej połowy XX wieku (o związkach między ciałem a społeczeństwem i kulturą jako jedni z pierwszych pisali Marcel Mauss i Norbert Elias). Innymi słowy, wydana we Francji w 2005 roku trzytomowa praca Histoire du corps wpisuje się w już jakoś ukształtowane pole dociekań nad dziejami cielesności. Historia ciała jako dziedzina czy subdyscyplina badawcza ma swą własną historię. Czy dałoby się w niej wyróżnić jakieś etapy i do którego z nich można by zaliczyć omawianą pracę? Ograniczając się do historiografii francuskiej, należałoby - w sposób cokolwiek schematyczny - wskazać trzy nurty badań nad ciałem. Pierwszy z nich, związany z dynamicznie rozwijającą się w latach pięćdziesiątych i sześćdziesiątych Braudelowską historią totalną, która kładła nacisk na geograficzne, materialne i społeczne uwarunkowania życia ludzi, umieszczał cielesność w obszarze demografii, patologii historycznej, oddziaływań klimatu, historii żywienia itd. Ciało i historyczność jego trwania, ciało jako cel ataku wirusów i mikrobów, ciało w danym ekosystemie, ciało jako siedlisko procesów metabolicznych - oto tematy, które interesowały ówcześnie historyków. Przedstawiciele drugiego nurtu, którego początek można datować na pierwszą połowę lat siedemdziesiątych ubiegłego stulecia, rozpatrują ciało w sferze polityki. Tutaj pracą fundamentalną jest oczywiście Nadzorować $i$ karać Michela Foucaulta, ale nie należy zapominać, że badania z zakresu owej „historii politycznej ciała” prowadzone były również później i trwają właściwie do dziś. Świadczą 
o tym choćby wydane już w XXI wieku książki Arlette Farge na temat związków między mechanizmami władzy a cielesnością w późnonowożytnej Francji (np. Effusion et tourment, le récit des corps. Histoire du peuple au XVIIIe siècle z 2007 roku) czy analizy Jean-Jacques'a Courtine'a dotyczące modelowania ciał przez współczesne urządzenia społeczne (Déchiffrer le corps z 2011 roku). Wreszcie trzecim nurtem byłaby historia kulturowa ciała, której narodziny trzeba by wiązać ze zwrotem kulturowym, jaki nastąpił w historiografii francuskiej na początku lat siedemdziesiątych wraz z wyłonieniem się tzw. nowej historii. Wówczas to grono historyków francuskich, niejako w opozycji do dominujących wcześniej badań prowadzonych $\mathrm{w}$ duchu Braudelowskiej histoire totale, zaczęli dowartościowywać znaczenie pomijanych dotąd czynników kulturowych - wyobrażeń, nawyków mentalnych, wierzeń itd. W orbitę tych zmian weszło również ciało jako przedmiot historycznego namysłu.

Historia ciata, jak się wydaje, kontynuuje tę trzecią tradycję. Nie oznacza to rzecz jasna, że nie pojawiają się w niej wątki społeczne, „fizyczne” czy polityczne. Jednakże główna oś recenzowanej pracy - i widać to wyraźnie w drugim tomie - wyznaczona jest przez perspektywę kulturową. Mówi się w niej zatem przede wszystkim o tym, jak określone aspekty cielesności sobie wyobrażano, jak je postrzegano, jakie przyjmowano wobec nich postawy, jakie nadawano im znaczenia, jak je konceptualizowano (np. w medycynie), jak zmieniały się progi wrażliwości wobec nich itd. Zresztą owo przesunięcie w stronę historii kulturowej zostało zasygnalizowane w Przedmowie do całego dzieła, gdzie po przypomnieniu, że historyczne zainteresowanie ciałem w pierwszym rzędzie rekonstruuje „serce cywilizacji materialnej”, jego „podstawowe ramy fizyczne”, a więc „człowieka z krwi i kości”, „człowieka zmysłowego”, możemy przeczytać: „Trzeba jednak uczynić to pojęcie ciała jeszcze bardziej złożonym, wykazać rolę, jaką odgrywają tu wyobrażenia, wierzenia, przejawy świadomości - nie chodzi o nic innego, jak o z pozoru "fikcyjną" przygodę z jej uwewnętrznionymi punktami odniesienia, dublującymi bezpośrednie punkty odniesienia, nadającymi im inna siłę i sens" (t. I, s. 6). I nie jest to deklaracja bez pokrycia. Kiedy więc w części 5 tomu II Alain Corbin pisze o ciele w kontekście seksualności, swoje wywody podsumowuje w następujący sposób: „Wszystko, o czym dotąd powiedzieliśmy, o tym świadczyło - historii ciała nie można 
oddzielić od historii spojrzenia, którym się je ogarnia” (t. II, s. 189). Kiedy z kolei mowa jest o ciele robotnika w XIX wieku, historyk zwraca uwage przede wszystkim na „ewolucję społecznego imaginarium”, mającego je za swój przedmiot odniesienia oraz na sposoby „patrzenia na nie właściwe elitom” (t. II, s. 230). W związku z ową kulturową dominantą perspektywy obranej przez redaktorów i autorów omawianego dzieła rodzą się dwa pytania natury metodologicznej.

Po pierwsze, z jakiego rodzaju pisarstwem historiograficznym się tu spotykamy? Swego czasu, w eseju zatytułowanym Brzemię historii, Hayden White, analizując Kulture Odrodzenia we Wtoszech Jacoba Burckhardta, nazwał tę książkę „ćwiczeniem z historiografii impresjonistycznej”. White sugerował $\mathrm{w}$ ten sposób między innymi zwrot szwajcarskiego historyka w stronę sztuki jako źródła inspiracji dla budowania historycznych opowieści oraz odrzucenie dogmatu dziewiętnastowiecznej historiografii, który polegał na szeregowaniu faktów w porządku chronologicznym zgodnie ze schematem przyczynowo-skutkowym. Otóż wydaje się, że współczesna historia kulturowa pod tym względem bardzo wyraźnie nawiązuje do swych źródeł (pracę Burckhardta uznaje się za pionierską dla tego nurtu); że w przypadku Historii ciata mamy do czynienia ze swego rodzaju techniką impresjonistyczną. Spójrzmy na przykład na taki fragment:

Nie sposób zrozumieć [...] nowego etapu historii wyobrażeń homoseksualizmu bez odwołania się do kontekstu, który go ukształtował. Obsesja wynaturzenia i regresu, związana z postępem cywilizacji, obawa przed spadkiem liczby urodzeń, strach przed zarażeniem się którąś z chorób wenerycznych, pogląd, że rosnący w siłę feminizm prowadzi do mnożenia się bezużytecznych brzuchów, kryzys męskiej tożsamości [...] pod koniec wieku, w którym mężczyzna nigdy nie był dumny ze swego ciała, potrzeba zakotwiczenia a contrario wzorca heteroseksualności, szeroko rozpowszechnione przekonanie o załamaniu się ładu moralnego, począwszy od połowy lat dziewięćdziesiątych, oraz - jeśli chodzi o Francję - niemiecki kryzys myśli francuskiej, który następuje po klęsce militarnej - wszystko to stanowi zbiór danych, którego echem jest nowy obraz homoseksualizmu (t. II, s. 185).

Widać bardzo wyraźnie, że więcej się tu sugeruje, niż jednoznacznie stwierdza, więcej się poddaje pod samodzielny namysł, niż ściśle wyjaśnia. 
Autor na przykład nie ustanawia hierarchii między wymienionymi zjawiskami w kontekście ich wpływu na nowy wizerunek homoseksualizmu, nie stosuje też żadnego modelu eksplanacyjnego, lecz - właśnie niczym malarz impresjonista - luźno i bez wyznaczenia między nimi określonych związków zestawia na jednej płaszczyźnie kilka elementów, z których odbiorca powinien sobie ułożyć w umyśle jednolity obraz (w tym przypadku: dziewiętnastowieczny obraz homoseksualizmu).

Drugie pytanie odnosi się do kwestii konceptualizacji przedmiotu badań. Jak mówi nam o tym tytuł całego dzieła, a także chyba intencje jego redaktorów i autorów, chodzi o napisanie historii ciała od wczesnej epoki nowożytnej do czasów współczesnych. Ale jak rozumie się tutaj ciało? Czy również w tym przypadku głównej roli nie odgrywa „technika impresjonistyczna”, to znaczy pojęcie ciała funkcjonujące w tej książce musi zostać zrekonstruowane ex post? A może „ciało” jest tu tylko - w dosłownym sensie - p retekstem dla rozważań na inne tematy, w jakiś sposób z ciałem związane? Czyż bowiem, przykładowo, wyobrażenia o takich czy innych aspektach cielesności nie wpisują się dużo bardziej w historię określonych dyskursów (medycznego, religijnego itd.) aniżeli w historię ciała jako takiego? Pytania te, które bynajmniej nie mają charakteru retorycznego i wymagają rozstrzygnięcia po szczegółowej analizie wszystkich trzech tomów omawianej pracy, są ważne o tyle, o ile odpowiedzi na nie mają decydujące znaczenie dla podstawowej kwestii: czy z przedstawionych w Histoire du corps wywodów da się zrekonstruować jakąś genealogię ciała współczesnego, a więc naszej cielesności? Klasyczne dzieła odnoszące się do tej problematyki formułowały w tym względzie precyzyjne i niezwykle oryginalne tezy: na przykład dla Eliasa ciało współczesnego człowieka Zachodu to przede wszystkim ciało „ucywilizowane”, a więc powściągające swoje popędy i impulsy (nie bez szkody dla ludzkiej psychiki), co stanowi efekt długiego i wciąż postępującego procesu specyficznie rozumianej cywilizacji. Z kolei dla Foucaulta - przynajmniej z okresu Nadzorować i karać oraz Woli wiedzy - ciało współczesne to ciało „zdyscyplinowane”, „ujarzmione”, którego siły zostały włączone, spożytkowane i w ramach owego użytku zmultiplikowane przez różnorakie urządzenia (dispositifs) władzy-wiedzy. Jaką (i czy w ogóle) odpowiedź daje na to pytanie Historia ciata? Wydaje się, że rozwiązanie tego problemu w dużym stopniu będzie decydować o wadze 
omawianej pracy i miejscu, jakie zajmie ona w ramach historycznych studiów nad cielesnością ludzi kultury zachodniej.

Tomasz Falkowski (Poznań) 